\title{
Absolute Value
}

\section{A Study in Christian Theism \\ DOM ILLTYD TRETHOWAN}

Works up to conclusions about man's knowledge of God which are not in themselves novel (they could hardly be plausible if they were), but are expounded and defended in ways which will strike most readers as novel. The author claims to adopt a strictly empirical method, but he also claims that human experience is metaphysical.

Muirhead Library of Philosophy Series

\section{Ethies and Christianity \\ KEITH WARD}

Explores the logic of Christian ethics in the light of contemporary moral philosophy. As it expounds a specific moral viewpoint which has been neglected in much recent discussion, this book will be important to moral philosophers; and will also be of great interest to theologians, as an outline of the basic framework of Christian ethics, offering a constructive discussion of revelation and authority.

Muirhead Library of Philosophy Series

\section{Bualalhist Ethies}

\section{Essence of Buddhism}

\section{H. SADDHATISSA}

Venerable Dr H. Saddhatissa, a Buddhist scholar-monk of over forty years standing, is eminently qualified to write on this subject. His book deals with its subject comprehensively yet it will readily appeal to enquirer and scholar alike. The special merit of this analysis consists in being a unlque study of a hitherto untreated aspect of Buddhism.

\section{Dimensions of Islame FRITHJOF SCHUON \\ Translated by PETER TOWNSEND}

The author, internationally celebrated for his studies in comparative religion, brings to light some important, but lesser known, aspects of Islam. Of particular interest to Western readers will be the chapters on Christ and the Virgin Mary, who for Moslems as well as for Christians is the summit of hierarchy of women.

\section{Classical Islam}

A History, 600-1258

G. E. VON GRUNEBAUM

Translated by KATHERINE WATSON

This authoritative work examines the relationship, both cultural and political, between the Isiamic world and the Mediterranean countries and India. Also it elaborates the economic, social and intellectual forces which shaped the Muslim world and its relationship with the 'infidels'.

Illustrated 60s

\section{George Allen \& Unwin}




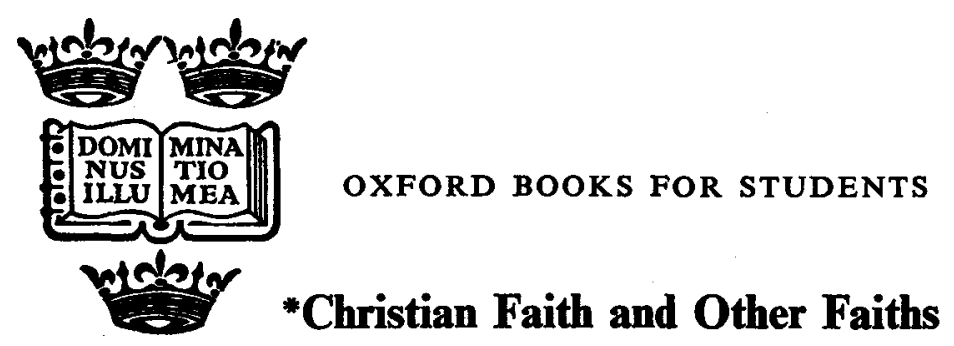

The Christian Dialogue with other Religions

Stephen Neill, Professor of Philosophy and Religion, University College of Nairobi

In this assessment of non-Christian religions from a Christian standpoint, Bishop Neill discusses the faith of contemporary primitive people as well as the main established religions, and modern forms of secularism, including a discussion of Existentialism. Christendom is then reconsidered in its relation to other faiths. The 1961 hard-cover edition has been revised throughout and new material added for this second edition in Oxford Paperbacks. 15/-

\section{The Later Christian Fathers}

A selection from the writings of the Fathers from St Cyril of Jerusalem to St Leo the Great

\section{Edited and translated by Henry Bettenson}

These extracts continue the story of the development of Christian doctrine begun in Mr Bettenson's The Early Christian Fathers. This period saw the consolidation of the Trinitarian faith, the explicit assertion of the divine personality of the Holy Spirit, and the search for an adequate foundation of the Christian belief that "God was in Christ reconciling the world unto himself', a search which ended in the statement of the Council of Chalcedon in 451. This volume includes writings of Basil the Great, Gregory of Nyssa, John Chrysostom, Jerome, Augustine of Hippo, and Cyril of Alexandria. $30 \%$

\section{Law, Morality, and Religion in a Secular Society}

Basil Mitchell, Nolloth Professor of the Philosophy of the Christian Religion, University of Oxford

Should the law be concerned only with actions which harm individuals or may it be used to protect the morality and essential institutions of a society? Professor Mitchell traces the differing views on this question expressed by Lord Devlin, Professor H. L. A. Hart, and others, to their origin in fundamental differences about the scope and nature of morality. This Oxford Paperbacks edition replaces the 1967 hard-cover edition. 7/-

NEW CLARENDON BIBLE

\section{*Israel Under Babylon and Persia}

\section{Peter R. Ackroyd}

Covers the period of Old Testament history during which the control of Palestine was in the hands first of the Babylonians and then of the Persians, from the fall of Jerusalem in 587 B.c. to the conquests of Alexander the Great. $30 /-$

\section{**St John}

\section{J. C. Fenton}

Written from an untraditional standpoint, this book presents the evangelist as a creative writer rather than a chronicler. 30/- 


\title{
The Logic of Divine Love
}

A Critical Analysis of the Soteriology of Peter Abailard

Richard E. Weingart

This book introduces the dialectical theology of Abailard and presents the most important results of Abailardian studies and researches. The influence of Abailard's thought on his contemporaries of different schools is traced in detail. $50 /-$

\section{Scripta Leonis, Rufini, et Angeli, Sociorum S. Francisci}

The Writings of Leo, Rufino, and Angelo, Companions of St. Francis

Edited and translated by Rosalind B. Brooke

The Mirror of Perfection is one of the most vivid collections of stories about St Francis of Assisi, and the most attractive and refreshing account of the saint that we possess. It is here published for the first time in English, with a critical Latin text and introduction. Leo's other work, the Life of St Francis's third disciple, Brother Giles of Assisi, is also included. 8 text-figures $80 /$ Oxford Medieval Texts

\section{Rousseau's Religious Writings}

\section{Ronald Grimsley}

Rousseau's religious writings have hitherto been dispersed among the many volumes of his work and correspondence. Professor Grimsley has here brought them together for the benefit of all who wish to base a comprehensive view of Rousseau's religion upon an adequate knowledge of his actual writings. $70 /-$

\section{Victorian Quakers}

\section{Elizabeth Isichei}

The importance of the Quaker Church in Victorian England was quite disproportionate to its size, especially in the spheres of industry and philanthropy. This social history of it will be of value to students of the sociology of religion and of Victorian history. 65/-Oxford Historical Monographs

\section{The Puritan Lectureships}

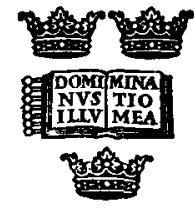

Oxford University Press

The Politics of Religious Dissent 1560-1662

\author{
Paul S. Seaver
}

f6 Stanford University Press

\section{The Shaping of American Religion}

Edited by James Ward Smith and A. Leland Johnson

30/-Princeton Paperbacks Princeton University Press 
Cambridge Studies in Social Anthropology 2 Buddhism and the Spirit Cults in North-East Thailand

\section{S. J. TAMBIAH}

As an anthropologist, $\mathrm{Dr}$ Tambiah is principally concerned with the contemporary village situation as it manifests itself to the observer. His objective is not merely to give an ethnographic account but to elucidate the symbolic meaning of the rituals and to relate these rituals to the way of life of the villagers and the structure of their society.

$£ 5$ 5s, net

\section{A Variety of Catholic Modernists}

The Sarum Lectures in the University of Oxford for the year 1968-9

\section{ALEC R. VIDLER}

Dr Vidler is here concerned primarily with the ideas and attitudes of the men who were implicated in the modernist movement, rather than with the movement itself. Having had access to many hitherto unpublished letters and personal sources of information, he is able to describe the characters of the modernists in lively detail.

50s. net

\section{CAMBRIDGE UNIVERSITY PRESS}

\section{TIME TO PUBLISH YOUR BOOK?}

We publish religious and academic books that meet exacting demands. Our special imprint, Testament Books, is reserved for the religious scholar.

Publication is rapid-within four months! Exposition's years of experience with religious works, texts, poetry and essays assure professional editing and promotion, quality book design and manufacture.

FREE: We invite your manuscripts for prompt editorial and cost appraisal. Write for answers to your special questions, and for literature on our publishing story, writing and contracts, with selections from our current book lists.

\section{Write to EXPOSITION PRESS}

Dept. 292E, 50 Jericho Turnpike, Jericho, N.Y. 11753, U.S.A. 


\section{Notes for CONTRIBUTORS}

1. Contributions and books for review should be sent to the editor, Professor H. D. Lewis, King's College, Strand, London, W.C.2. Books published in America should be sent to Professor J. E. Smith, Department of Philosophy, Yale University, New Haven.

2. Contributions should normally be in. English and should preferably be typewritten (doublespaced on quarto paper). Contributors should keep a copy themselves for use when correcting proofs.

3. Submission of an article is taken to imply that it has not previously been published, or is not being considered for publication elsewhere. If rejected manuscripts are to be returned, stamps or international coupons should be sent to cover postage.

4. All contributors receive 50 free separates. 


\section{Religious Studies}

Volume 6, Number 3, September 1970

\section{CONTENTS}

WALHOUT, DONALD

Other Religions as Sacred Reminders

STRENG, F. J.

The Objective Study of Religion and the Unique Quality of 209 Religiousness

VAUGHT, CARL G.

Two Concepts of God

NASR, SEYYED HOSSEIN

Shi'ism and Sufism: Their Relationship in Essence and in History

YOUNG, D. N. DE L.

The Sangha in Buddhist History

DALE, JOHN

Martin Buber's Semantic Puzzle

WOODHOUSE, MARK B,

Selves and Minds: A Reply to Professor Knox

KNOX, JOHN JR.

Reply to Professor Woodhouse

SIEFFERMAN, NORMAN C.

Science and Religion: A Reply to John F. Miller

HOFFMAN, ROBERT

On Being Mindful of 'God': Reply to Kai Nielsen

Reviews

\section{CAMBRIDGE UNIVERSITY PRESS}

Bentley House, 200 Euston Road, London, N.W.1

American Branch: 32 East 57 th Street, New York, N.Y.10022

26s. net $\$+.00$ in U.S.A. Subscription Price 80 s. net $\$ 13.50$ in U.S.A.

Religious Studies is indexed in the Index of Religious Periodical Literature 